\title{
Putative Endoplasmin-Like Protein
}

National Cancer Institute

\section{Source}

National Cancer Institute. Putative Endoplasmin-Like Protein. NCI Thesaurus. Code C116984.

Putative endoplasmin-like protein (399 aa, $46 \mathrm{kDa}$ ) is encoded by the human HSP90B2P gene. This protein may play a role in protein chaperone activity. 